\title{
PENGARUH PERGANTIAN AUDITOR, UKURAN KANTOR AKUNTAN PUBLIK, SOLVABILITAS DAN UMUR PERUSAHAAN TERHADAP AUDIT REPORT LAG
}

\author{
Romasi Lumban Gaol ${ }^{\mathbf{1}}$; Mariana Sitohang ${ }^{2}$ \\ ${ }^{1,2}$ Fakultas Ekonomi Program Studi Akuntansi Universitas Katolik Santo Thomas \\ romasilumbangaol@yahoo.co.id ${ }^{1}$ \\ $\underline{\text { marianasitohang0610@gmail.com }}{ }^{2}$
}

\begin{abstract}
ABSTRAK
Penelitian ini bertujuan untuk menganalisis pengaruh pergantian auditor, ukuran Kantor Akuntan Publik (KAP), solvabilitas dan umur perusahaan terhadap audit report lag pada perusahaan manufaktur yang terdaftar di BEI. Populasi penelitian ini adalah perusahaan manufaktur sektor industri dasar dan kimia yang terdaftar di BEI di tahun 2013-2018. Sampel pada penelitian ini didapatkan dengan cara purposive sampling, dengan jumlah sampel 26 perusahaan. Teknik pengumpulan data menggunakan teknik dokumentasi. Metode analisis yang digunakan adalah persamaan regresi linear berganda dengan menggunakan program SPSS 25. Dari hasil pengujian ditemukan bahwa, nilai koefisien determinasi (R Square) sebesar 0,092 ini berarti variabel bebas yaitu pergantian auditor, ukuran KAP, solvabilitas dan umur perusahaan secara bersama-sama mempengaruhi audit report lag sebesar 9,2\%. Berdasarkan hasil uji regresi linear berganda dapat disimpulkan bahwa, Pergantian auditor dan umur perusahaan berpengaruh negatif dan tidak signifikan terhadap audit report lag. Ukuran KAP dan solvabilitas berpengaruh positif dan signifikan terhadap audit report..
\end{abstract}

Kata kunci : Pergantian Auditor, Ukuran Kantor Akuntan Publik, Solvabilitas, Umur Perusahaan dan Audit Report Lag

\section{PENDAHULUAN}

Ketepatan waktu penyajian laporan keuangan berbanding lurus dengan relevansi dan keandalan laporan keuangan. Menurut Kim dan verrechia (dalam Desi, 2018) bahwa laporan keuangan yang disampaikan dengan tepat waktu akan mengurangi asimetri informasi, yang mendorong penyajian laporan keuangan secara penuh.

Keterlambatan waktu dalam penyampaian laporan keuangan tentunya menimbulkan reaksi negatif terhadap para pelaku pasar modal, dikarenakan laporan keuangan auditan tersebut dijadikan sebagai salah satu dasar bagi investor untuk mengambil keputusan dalam melakukan investasi terhadap suatu perusahaan. Investor akan menganggap keterlambatan pelaporan keuangan merupakan pertanda buruk bagi kesehatan perusahaan sehingga akan berdampak negatif terhadap reaksi pasar (Apitaningrum, 
2017). Jika reaksi pasar terhadap perusahaan sudah negatif, maka sinyal perusahaan terhadap investor juga buruk dan menimbulkan keraguan untuk menanamkan modal pada perusahaan tersebut.

Mengingat betapa pentingnya laporan keuangan bagi para pengambil keputusan, maka Otoritas Jasa Keuangan (OJK) selaku pengawas pasar modal BEI menetapkan peraturan dan sanksi mengenai penyampaian laporan keuangan tahunannya. Jika perusahaan atau emiten yang bersangkutan tidak mematuhi peraturan maka yang bersangkutan akan diberi sanksi oleh Otoritas Jasa Keuangan (OJK) yakni a). Peringatan tertulis; b).denda yaitu kewajiban untuk membayar sejumlah uang tertentu; c). Pembatasan kegiatan usaha; d). Pembekuan kegiatan usaha; e). Pencabutan izin usaha; f). Pembatalan persetujuan; g). Pembatalan pendaftaran.

Kasus keterlambatan perusahaan dalam menyampaikan laporan keuangan sebelumnya sudah pernah terjadi ditahun 2017, dilansir dari https://www.cnnindonesia.com bahwa terdapat 10 perusahaan emiten yang disuspensi oleh pihak BEI diakibatkan karena telat menyampaikan laporan keuangan. Disuspensi dalam hal ini berarti dilakukan pemberhentian aktivitas perdagangan saham sementara waktu.

Menurut Coki dalam blognya https://coki002.wordpress.com/ keuntungan-dan-kerugian-dalam investasi-saham/ jika suatu saham di suspenp atau diberhentikan perdagangannya oleh Otoritas Jasa Keuangan (OJK) maka pemodal tidak dapat menjual sahamnya hingga saham yang di suspend tersebut dicabut dari status suspend. Hal seperti ini tentunya akan menimbulkan kerugian bagi perusahaan maupun para investor, yang menyebabkan berkurangnya kepercayaan investor terhadap perusahaan.

Apabila perusahaan tidak ingin kena sanksi dari keterlambatan penyampaian laporan keuangan, maka rentang waktu penyelesaian audit oleh auditor harus sesuai dengan peraturan yang ditetapkan oleh OJK. Rentang waktu penyelesaian pelaksanaan audit laporan keuangan tahunan, diukur berdasarkan lamanya hari yang dibutuhkan untuk memperoleh laporan auditor atas audit laporan keuangan tahunan perusahaan, sejak tanggal tutup tahun perusahaan yaitu per 31 Desember sampai tanggal yang tertera pada laporan auditor didefinisikan sebagai audit repot lag (Apitaningrum, 2017). Semakin lama waktu yang dibutuhkan auditor menyelesaikan pekerjaan auditnya, maka semakin lama pula audit report lag. Jika audit report lag semakin lama, maka kemungkinan keterlambatan penyampaian laporan keuangan akan semakin besar. Oleh karena itu penelitian mengenai audit report lag menjadi objek yang tepat untuk 
mencari bukti empiris mengenai faktor-faktor yang berpengaruh terhadap audit report lag.

Dari uraian tersebut peneliti ingin membuktikan secara empiris apakah pergantian auditor, ukuran KAP, solvabilitas dan umur perusahaan berpengaruh terhadap audit report lag baik secara parsial dan simultanpada perusahaan manufaktur yang terdaftar di BEI pada tahun 2013-2018.

\section{TELAAH TEORI DAN PENGEMBANGAN HIPOTESIS}

\section{Telaah Teori}

\section{a. Teori Keagenan (Agency Theory)}

Menurut Arfan Ikhsan, dkk (2013:128), Teori keagenan (agency theory) saat ini merupakan hal yang penting dalam penelitian akuntansi. Adapun dasar yang melandasi munculnya teori keagenan adalah dimana individu-individu bertindak untuk kepentingan diri mereka sendiri sehingga terkadang mengabaikan kepentingan perusahaan.

Menurut Arfan Ikhsan, dkk (2013), teori keagenan bertujuan untuk menyelesaikan : (1) masalah agensi yang muncul ketika adanya konflik tujuan antara principal dan agen (2) masalah pembagian risiko yang muncul ketika principal dan agen memiliki perilaku yang berbeda terhadap risiko. Ketidaksesuaian informasi itu disebut asymmetric information antara pihak agen dan prinsipal (Jensen \& Meckling, 1976).

Dalam upaya untuk menekan masalah agensi ini diperlukan adanya pihak independen untuk menjembatani konflik antara principal dan agent (Safitri, 2018). Pihak independen adalah Kantor Akuntan Publik atau auditor independen. Jadi teori keagenan digunakan untuk membantu auditor sebagai pihak ketiga untuk memahami konflik kepentingan yang dapat muncul antara principal dan agent sehingga diharapkan tidak terjadi kecurangan dalam penyusunan laporan keuangan yang dapat menimbulkan tenggang waktu audit report lag yang berkepanjangan.

\section{b. Audit Report Lag}

Maharani (2017) menyatakan bahwa audit report lag merupakan rentang waktu penyelesaian audit dimulai dari tanggal tutup buku perusahaan sampai tanggal yang tercantum dalam laporan audit. Adanya audit report lag berakibat pada keterlambatan publikasi laporan keuangan yang mencerminkan adanya suatu masalah pada kondisi keuangan perusahaan. 
Faktor-faktor yang menyebabkan lamanya waktu penyelesaian pengaudit ini tidak terbatas pada faktor internal perusahaan saja, namun juga pada faktor eksternal juga. Faktor internal biasanya dipengaruhi oleh profitabilitas, umur perusahaan, laba rugi dan solvabilitas. Sedangkan faktor eksternal biasanya dipengaruhi oleh kualitas kantor Akuntan Publik (KAP) yang mengaudit laporan keuangan perusahaan yang bersangkutan ( Ilham, 2015).

Audit Report Lag (Waktu penyelesaian) dapat diukur dari jumlah hari. Audit repot lag dikatakan lambat jika lebih dari 90 hari dan dikatakan cepat dimulai dari 1- 90 hari Jumlah hari tersebut dapat dihitung dari tanggal penutupan tahun buku perusahaan dikurangi tanggal penerbitan laporan keuangan sehingga tampak seperti rumus berikut:

"Audit report lag= tanggal laporan audit- tanggal laporan keuangan."

\section{c. Pergantian Auditor}

Menurut Ahmed dan Hossain, (2010), Pergantian auditor merupakan putusnya hubungan auditor yang lama dengan perusahaan kemudian mengangkat auditor yang baru untuk menggantikan auditor yang lama. Pergantian auditor merupakan putusnya kerjasama antara seorang auditor dengan sebuah perusahaan. Uli (2014), mendefenisikan pergantian auditor adalah adanya pergantian auditor antara tahun berjalan dengan tahun sebelumnya.

Menurut Mulyadi (2002) klien yang mengganti auditornya tanpa alasan yang jelas, mungkin disebabkan oleh ketidakpuasan klien terhadap jasa yang diberikan oleh auditor lama. Dan penggantian auditor tersebut juga disebabkan oleh adanya perselisihan antara klien dengan auditor publiknya mengenai penyajian laporan keuangan dan pengungkapanya. Berdasarkan teori Mulyadi tersebut tujuan pergantian auditor adalah untuk mendapatkan hasil yang memuaskan dari kinerja auditor baru. Sedangkan manfaat pergantian auditor yaitu mencegah adanya kecurangan yang terjadi dalam penyampaian laporan keuangan.

Apabila perusahaan mengalami pergantian auditor tentunya auditor baru membutuhkan waktu yang cukup lama untuk mengenali karakteristik dan prosedur audit usaha klien dan sistem yang ada di dalamnya sehingga ini menyita waktu. Auditor dalam malaksanakan proses auditnya akan berpengaruh terhadap ketepatan waktu penyampaian laporan keuangan perusahaan. Dengan demikian pergantian auditor kemungkinan dapat mempengaruhi ketepatan waktu penyampain laporan keuangan. 
Pengukuran variabel pergantian auditor menggunakan variabel dummy, nilainya adalah 1 dan 0 . Jika perusahaan klien mengalami pergantian auditor maka diberikan nilai 1. Sedangkan jika perusahaan masih menggunakan auditor lama atau tidak mengalami pergantian auditor maka diberikan nilai 0 .

\section{d. Ukuran KAP}

Menurut Rizki (2019) bahwa KAP yang besar adalah KAP the big four dimana KAP the big four memiliki kecenderungan menyelesaikan pekerjaan auditnya lebih cepat untuk mempertahankan nama baik serta reputasi dari instansinya sehingga the big four memiliki motivasi yang lebih kuat .

Indikator yang digunakan dalam Ukuran KAP adalah Kantor Akuntan Publik di Indonesia dibagi menjadi KAP the big four dan KAP non the big four. KAP besar (The Big Four) adalah empat kantor akuntan publik yang sudah dipercaya reputasinya untuk menangani pekerjaan audit perusahaan besar.

Pengukuran variabel ukuran KAP menggunakan variabel dummy, nilainya adalah 1 dan 0 . Jika perusahaan menggunakan KAP the big four maka diberikan nilai 1 . Sedangkan jika perusahaan menggunakan KAP non the big four auditor maka diberikan nilai 0 .

\section{e. Solvabilitas}

Menurut Kasmir (2010: 151), rasio solvabilitas merupakan rasio yang digunakan untuk mengukur sejauh mana aktiva suatu perusahaan yang dibiayai dengan utang perusahaan. Penggunaan hutang yang terlalu tinggi akan berdampak pada masa depan perusahaan. Menurut Bahri, Hasan \& carvalho (2018) Semakin lama perusahaan dalam memenuhi kewajiban keuangan maka perusahaan bisa dikatakan mengalami kesulitan keuangan. Kondisi keuangan dari sebuah perusahaan dapat dilihat dari persentase hutang terhadap total aset yang dimiliki. Kondisi keuangan yang buruk merupakan berita buruk yang akan mempengaruhi citra perusahan di mata masyarakat. Persentase hutang yang besar akan meningkatkan kecenderungan kerugian dan dapat meningkatkan kehatihatian dari audior selama melaksanakan proses audit.

Penelitian ini sejalan dengan penelitian Andika (2015) bahwa indikator yang digunakan untuk mengukur solvabilitas perusahaan ialah Debt to Assets Ratio (DAR) karena rasio ini dapat mengindikasikan tingkat kesehatan suatu perusahaan. Selain itu, rasio ini dapat membandingkan antara jumlah seluruh hutang perusahaan terhadap kekayaan yang dimiliki 
perusahaan. Perhitungan Rasio Hutang atas Aktiva atau Debt to Assets Ratio (DAR) dihitung dengan rumus (Rahardjo, 2005: 121):

\section{f. Umur Perusahaan}

"Debt to Assets Ratio(DAR) $=\frac{\text { Totalutang }}{\text { Totalaktiva }}$ X 100\%."

Nugroho dalam Dewangga (2019), mendefinisikan umur perusahaan sebagai berikut: "Umur perusahaan merupakan awal perusahaan melakukan aktivitas operasional hingga dapat mempertahankan going concern perusahaan tersebut atau mempertahankan eksistensi dalam dunia bisnis". Umur perusahaan adalah lamanya waktu hidup suatu perusahaan yang menunjukkan bahwa perusahaan tetap eksis, mampu bersaing dalam dunia usaha dan mampu mempertahankan kesinambungan usahanya serta merupakan bagian dari dokumentasi yang menunjukan tujuan dari perusahaan tersebut. Menurut

Menurut Indra \&Arisudhana (2012) bahwa semakin tua perusahaan, investor akan menilai kinerja perusahaan lebih efisien dan informasi yang relevan dapat tersedia tepat waktu. Perusahaan yang umurnya lebih tua dinilai lebih terampil dalam mengumpulkan, memproses, dan menghasilkan informasi tepat waktu karena telah memiliki pengalaman yang cukup.

Menurut indriani (2013) umur perusahaan dilihat dari umur listing perusahaan, dimana umur listing perusahaan merupakan seberapa lama perusahaan terdaftar di BursaEfek Indonesia (BEI) sebagai perusahaan go public. Pernyataan yang dikemukakan oleh Indriani tersebut menunjukkan bahwa perusahaan juga dapat diukur dari tahun pencatatan umur listing perusahaan.

Dengan demikian, umur perusahaan dihitung dengan:

"Umur perusahaan= Tahun Penelitian - Tahun perusahaan tercatat di BEI"

\section{Pengembangan Hipotesis}

\section{a. Pengaruh Pergantian Auditor Terhadap Audit}

Menurut Uli (2014), Pergantian auditor adalah adanya pergantian auditor antara tahun berjalan dengan tahun sebelumnya. Pergantian auditor pada suatu perusahaan dilakukan dengan tujuan untuk menjaga independensi dari auditor agar tetap bersikap objektif dalam melakukan tugasnya sebagai auditor.

Verawati\&widiakusuma(2016), apabila perusahaan mengalami pergantian auditor, tentunya auditor baru memerlukan waktu yang cukup 
lama untuk mengenali karakteristik usaha klien dan sistem yang ada di dalamnya dikarenakan auditor baru tidak memiliki pemahaman dan pengetahuan spesifik mengenai bisnis klien dibandingkan dengan auditor sebelumnya sehingga hal ini menyita waktu auditor dalam melaksanakan proses auditnya.

Oleh karena itu, jika perusahaan mengalami pergantian auditor maka cenderung mengalami audit report lag yang lama dan jika perusahaan masih bekerjasama dengan auditor yang lama menyebabkan audit report lag yang cepat

\section{b. Pengaruh Ukuran KAP terhadap Audit Report Lag}

Kualitas audit dari sebuah Kantor Akuntan Publik dapat dilihat dari KAP yang melakukan proses audit. Ukuran KAP dilambangkan dengan the big four dan the non big four. KAP yang tergolong the big four dapat diyakini lebih berkualitas dibandingkan dengan KAP non the big four. KAP the big four dianggap mampu untuk mengakses teknologi yang canggih dan kemampuan sumber daya yang lebih profesional. Dengan sumber daya manusia yang berkualitas tentunya akan mempercepat dalam melakukan proses audit sehingga tidak menyebabkan adanya keterlambatan dalam penyampaian laporan keuangan tahunan. (Rachmawati, 2008).

Penelitian yang dlakukan Abernathy, et al (2016) bahwa perusahaan yang diaudit oleh KAP the big four memiliki audit report lag yang lebih pendek. Hal ini terkait dengan ketepatan waktu pelaporan keuangan, yakni dilihat dari laporan keuangan yang di audit oleh KAP.

Oleh karena itu, dapat disimpulkan bahwa perusahaan yang berkolaborasi dengan kantor akuntan publik yang besar (Big four) cenderung melaporkan laporan keuangan dengan tepat waktu atau mengalami audit report lag pendek. Dan perusahaan yang berkolaborasi dengan KAP yang non Big Four akan mengalami audit report lag yang panjang.

\section{c. Pengaruh Solvabilitas terhadap Audit Report Lag}

Solvabilitas adalah kemampuan perusahaan untuk memenuhi segala kewajiban keuangannya pada saat perusahaan di likuidasi (Lianto dan Kusuma, 2010). Rasio solvabilitas digunakan untuk mengukur seberapa jauh aktiva perusahaan dapat membayar utang perusahaan.

Penelitian Dura (2017) menyatakan adanya pengaruh solvabilitas terhadap audit report lag yang mengindikasikan bahwa kecilnya kemampuan perusahaan dalam membayar kewajiban-kewajiban perusahaan akan menyebabkan proses audit yang lebih panjang. Hal ini 
juga sejalan dengan Maharani (2017), Rasio solvabilitas yang tinggi menunjukkan tingginya rasio keuangan dan menggambarkan perusahaan mengalami kesulitan keuangan. Proporsi hutang terhadap total aktiva yang tinggi akan meningkatkan kecenderungan kerugian dan dapat meningkatkan kehati-hatian dari auditor terhadap laporan keuangan yang akan diaudit.

Semakin tinggi tingkat hutang akan meningkatkan resiko keuangan perusahaan. Perusahaan yang memiliki kondisi keuangan yang tidak sehat cenderung dapat melakukan salah kelola dan kebangkrutan. Dengan demikian kehati-hatian auditor dalam menyelesaikan audit laporan keuangan akan mengakibatkan keterlambatan dalam menyampaikan laporan keuangan kepada publik.

Maka semakin tinggi tingkat solvabilitas suatu perusahaan maka semakin lama audit report lagnya dan semakin rendah solvabilitas suatu perusahaan akan menyebabkan audit report lag semakin cepat.

\section{d. Pengaruh Umur Perusahaan terhadap Audit Report Lag}

Saemargani (2015) mengatakan bahwa umur perusahaan mempunyai pengaruh terhadap audit report lag. Semakin lama umur perusahaan investor akan menilai bahwa perusahaan tersebut akan semakin efisien sehingga informasi yang relevan dapat disajikan tepat waktu.

Umur perusahaan yang dimaksudkan dalam penelitian ini adalah umur perusahaan yang dihitung sejak perusahaan tersebut telah di bursa efek Indonesia. Penelitian Petronila dalam Lianto \&Kusuma (2010) menunjukan bahwa umur perusahaan memiliki pengaruh signifikan terhadap audit report lag. Semakin lama umur suatu perusahaan maka jangka waktu penyelesaian audit hingga laporan diterbitkan akan semakin cepat demikian pula sebalik.

Oleh karena itu semakin lama umur perusahaan maka audit report lag yang terjadi akan semakin singkat. Hal tersebut dikarenakan perusahaan yang memiliki umur yang lebih lama dinilai lebih mampu dan terampil dalam mengumpulkan, memproses, dan menghasilkan informasi pada saat diperlukan karena telah memiliki pengalaman yang banyak.Adapun kerangka berpikir dalam penelitian ini dapat disajikan pada gambar di bawah ini:

\section{e. Kerangka Pemikiran Teoritis}

Kerangka pemikiran disusun untuk menggambarkan pengaruh antara variabel independen dengan variabel dependen. Kerangka pemikiran dapat digambarkan seperti di berikut: 
Pengaruh Pergantian Auditor, Ukuran Kantor Akuntan Publik, Solvabilitas

Dan Umur Perusahaan Terhadap Audit Report Lag

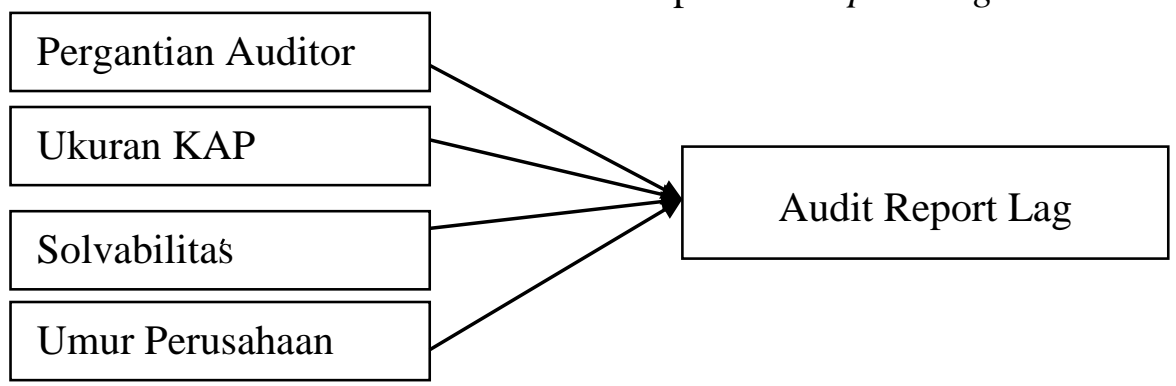

\section{f. Hipotesis Penelitian}

adalah:

Berdasarkan kerangka berfikir diatas, maka hipotesis penelitian ini

H1 : Pergantian auditor berpengaruh positif dan signifikan terhadap audit report lag pada perusahaan manufaktur sektor industri dasar dan kimia yang terdaftar di Bursa Efek Indonesia tahun 2013-2018.

H2 : Ukuran KAP berpengaruh negatif dan signifikan terhadap audit report lag pada perusahaan manufaktur sektor industri dasar dan kimia yang terdaftar di Bursa Efek Indonesia tahun 2013-2018.

H3 : Solvabilitas berpengaruh positif dan signifikan terhadap audit report lag pada perusahaan manufaktur sektor industri dasar dan kimia yang terdaftar di Bursa Efek Indonesia tahun 2013-2018.

H4: Umur perusahaan berpengaruh negatif dan signifikan terhadap audit report lag pada perusahaan manufaktur industri dasar dan kimiayang terdaftar di Bursa Efek Indonesia tahun 2013-2018.

\section{METODE PENELITIAN}

\section{Populasi dan Sampel}

Populasi dalam penelitian ini adalah Perusahaan manufaktur sektor indutri dasar dan kimia tahun 2013-2018 yang terdaftar di Bursa Efek Indonesia. Teknik pengambilan sampel dalam penelitian ini menggunakan metode purposive sampling. Berdasarkan teknik pengambilan sampel tersebut diperoleh sampel sebanyak 26 dengan periode pengamatan selama 6 tahun yaitu 2013-2018. Oleh karena itu, total sampel sebanyak $26 \times 6=$ 156 laporan tahunan perusahaan manufaktur sektor industi dasar dan kimia yang terdaftar di Bursa Efek Indonesia. 


\section{Operasionalisasi Variabel Penelitian}

a. Audit Report Lag

Afify (2009) menyatakan bahwa audit report lag merupakan rentang waktu penyelesaian audit dimulai dari tanggal tutup buku perusahaan sampai tanggal yang tercantum dalam laporan audit.Variabel ini diukur dengan

Audit Report Lag = Tanggal Laporan Audit - Tanggal Laporan Keuangan

b. Pergantian Auditor

Menurut Primsa, dkk (2018) Pergantian auditor adalah adanya pergantian auditor antara tahun berjalan dengan tahun sebelumnya. Pengukuran variabel pergantian auditor menggunakan variabel dummy. Jika perusahaan klien mengalami pergantian auditor maka diberikan nilai 1. Sedangkan jika perusahaan tidak mengalami pergantian auditor maka diberikan nilai 0 .

\section{c. Ukuran KAP}

Menurut Arifa (dalam Fitriyani, 2015) bahwa ukuran Kantor Akuntan Publik merupakan besar kecilnya sebuah KAP. Pengukuran variabel ukuran KAP menggunakan variabel dummy. Jika perusahaan menggunakan KAP the big four maka diberikan nilai 1. Sedangkan jika perusahaan menggunakan KAP non the big four auditor maka diberikan nilai 0.

\section{d. Solvabilitas}

Menurut Sofyan Syafri Harahap (2011: 303) solvabilitas menggambarkan kemampuan perusahaan dalam membayar kewajiban jangka panjangnya apabila perusahaan dilikuidasi. Solvabilitas diukur menggunakan total hutang dan total aset. Solvabilitas diukur dengan rumus berikut :

$$
\text { Debt to Assets Ratio(DAR) }=\frac{\text { Total utang }}{\text { Total Aset }} \text { X 100\%. }
$$

\section{e. Umur Perusahaan}

Umur perusahaan dalam penelitian ini dihitung dari selisih antara tahun penelitian dengan tahun terdaftarnya perusahaan di BEI, (Liu \& Anbumozhi 2008) dan Hossain \& Hammami, 2009). Dengan demikian, umur perusahaan dihitung dengan:

"Umur perusahaan= Tahun Penelitian - Tahun perusahaan tercatat di BEI" 


\section{Teknik Analisis Aata}

Teknik analisis data yang digunakan dalam penelitian ini adalah analisis regresi linear berganda, koefisien determinasi, uji statistik F dan uji statistik t. Adapun analisis yang dilakukan adalah sebagai berikut:

\section{a. Analisis Regresi Linear Berganda}

Menurut Ghozali (2013), dalam analisis regresi, selain mengukur kekuatan hubungan antara dua varibel atau lebih, juga menunjukan arah hubungan antar variabel dependen dengan variabel independen. Untuk mengetahui pengaruh variable bebas dan variable terikat digunakan rumus analisis regresi linear berganda sebagai berikut :

$$
\hat{\mathrm{Y}}=\mathrm{bo}+\mathrm{b} 1 \mathrm{X} 1+\mathrm{b} 2 \mathrm{X} 2+\mathrm{b} 3 \mathrm{X} 3+\mathrm{b} 4 \mathrm{X} 4+\varepsilon
$$

$$
\begin{aligned}
& \text { Keterangan: } \\
& \hat{\mathrm{Y}} \quad=\text { Audit Report Lag } \\
& \mathrm{X} 1=\text { Pergantian Auditor } \\
& \mathrm{X} 2=\text { Ukuran KAP } \\
& \mathrm{X} 3 \quad=\text { Solvabilitas } \\
& \mathrm{X} 4 \quad=\text { Umur Perusahaan } \\
& \text { b0 } \quad=\text { Intersep } \\
& \mathrm{b} 1, \mathrm{~b} 2, \mathrm{~b} 3, \ldots \mathrm{b} 4=\text { koefesien regresi } \\
& \varepsilon \quad=\text { standar eror }
\end{aligned}
$$

\section{b. Uji Asumsi Klasik}

Sebelum model regresi digunakan untuk menguji hipotesis, tentunya model tersebut harus bebas dari gejala asumsi klasik karena model yang baik harus memenuhi kriteria BLUE (Best Linear Unbiased Estimator). Adapun uji asumsi klasik yang digunakan adalah, Uji Normalitas, normalitas diuji dengan melihat grafik histogram (Ghozali, 2013). Uji Multikolinieritas, pengujian multikolinearitas dilakukan dengan melihat VIF (Variance Inflation Factor) antar variabel independen, (Ghozali, 2013)

Uji Autokorelasi, pengujian autokorelasi menggunakan uji Durbin - Watson (DW test). Uji Heteroskedastisitas Uji heteroskedastisitas dilakukan dengan melihat grafik plot antara nilai prediksi variabel terikat(dependen) yaitu ZPRED dengan residualnya SRESID (Ghozali, 2013:139).

\section{c. Pengujian hipotesis penelitian}

Pengujian hipotesis dilakukan dengan uji koefisien determinasi, uji statistik F dan uji statistik t. 


\section{HASIL PENELITIAN DAN PEMBAHASAN}

\section{Statistik Deskriptif}

Statistik deskriptif dalam penelitian ini disajikan untuk memberikan informasi karakteristik variabel penelitian khususnya mengenai mean dan deviasi standar. Pengukuran mean merupakan cara yang paling umum digunakan untuk mengukur nilai sentral dari suatu distribusi data. Deviasi standar merupakan perbedaan antara nilai data yang diteliti dengan nilai rata-ratanya. Berikut ini disajikan hasil statistik deskriptif pengujian pengaruh Perputaran Persediaan Perputaran Piutang, Tingkat Pertumbuhan Penjualan terhadap Likuiditas pada Tabel 1 berikut ini:

Tabel 1 Hasil Uji Statistik Deskriptif

\begin{tabular}{lr|r|r|r|r} 
& \multicolumn{5}{c}{ Descriptive Statistics } \\
& $N$ & Minimum & Maximum & Mean & \multicolumn{1}{c}{ Std. Deviation } \\
\hline Pergantian Auditor & 156 & 0 & 1 & .50 & .502 \\
\hline Ukuran KAP & 156 & 0 & 1 & .39 & .490 \\
\hline Solvabilitas & 156 & 7.15 & 125.41 & 47.5501 & 25.66713 \\
\hline Umur Perusahaan & 156 & 2 & 30 & 17.46 & 7.892 \\
\hline Audit Report Lag & 156 & 22 & 173 & 85.56 & 19.454 \\
\hline Valid N (listwise) & 156 & & & & \\
\hline
\end{tabular}

Sumber : Data sekunder diolah 2020

Tabel diatas menunjukkan bahwa, audit report lag memiliki ratarata sebesar 85,56 dan nilai standar deviasi 19,454. Nilai maksimum 173 hari, dan nilai Minimum 22 hari. Pergantian auditor diukur memiliki nilai maksimum 1 dan nilai minimumnya 0 . Pergantian auditor memiliki ratarata 0,50 dan nilai standar deviasi 0,502 .

Ukuran KAP memiliki nilai maksimum yaitu 1 dan nilai minumnya 0 . Nilai rata-rata 0,39 dan nilai standar deviasi 0,490 . Solvabilitas memiliki rata-rata 47,5501 dan nilai standar deviasi 25,66713. Nilai maksimum $125,41 \%$ dan nilai minimum $7,15 \%$. Umur perusahaan memiliki rata-rata 17,46 dan nilai standar deviasi 7,892. Nilai maksimum 30 tahun dan nilai minum 2 tahun.

\section{Pengujian Hipotesis}

Pada penelitian ini, penguji dilakukan dengan analisis linear berganda, yaitu suatu metode statistik yang umum digunakan untuk meneliti hubungan antara sebuah variabel dependen dengan variabel independen. Adapun model regresi linear yang digunakan adalah sebagai berikut 
Tabel 2. Analisis Regresi Berganda

\begin{tabular}{|c|c|c|c|c|c|c|}
\hline \multicolumn{7}{|c|}{ Coefficients $^{a}$} \\
\hline \multirow{2}{*}{\multicolumn{2}{|c|}{ Model }} & \multicolumn{2}{|c|}{ Unstandardized Coefficients } & \multirow{3}{*}{$\begin{array}{c}\text { Standardized } \\
\text { Coefficients } \\
\text { Beta } \\
\end{array}$} & \multirow[b]{2}{*}{$t$} & \multirow[b]{2}{*}{ Sig. } \\
\hline & & B & Std. Error & & & \\
\hline 1 & (Constant) & 62.483 & 6.384 & & 9.788 & .000 \\
\hline & Pergantian Auditor & -.063 & 2.916 & -.002 & -.022 & .983 \\
\hline & Ukuran KAP & 10.179 & 3.203 & .256 & 3.178 & .002 \\
\hline & Solvabilitas & .281 & .065 & .371 & 4.304 & .000 \\
\hline & Umur Perusahaan & -.327 & .227 & -.133 & -1.443 & .151 \\
\hline
\end{tabular}

a. Dependent Variable: Audit Report Lag

Sumber : Data sekunder diolah, 2020

Berdasarkan tabel diatas, dapat dirumuskan permasaan regresi berganda sebagai berikut:

Audit Report Lag $=62,483-0,63+10,179 X 2+0.281 X 3-0,327$ X4 + $\varepsilon$

Berdasarkan persamaan regresi tersebut dapat dianalisis pengaruh masing- masing variabel independen terhadap audit report lag yaitu:

1. Nilai konstanta adalah 62,483 artinya jika variabel pergantian auditor, ukuran KAP, solvabilitas dan umur perusahaan bernilai 0 , maka audit report lag sebesar konstanta yaitu sebesar 62,483.

2. Nilai koefisien pergantian auditor adalah -0,063. Hal ini menunjukkan bahwa setiap perusahaan melakukan pergantian auditor yang diukur dengan dummy memiliki audit report lag lebih cepat 0,063 hari dibandingkan perusahaan yang tidak melakukan pergantian auditor. Hal ini berarti bahwa pergantian auditor memiliki pengaruh negatif terhadap audit report lag pada perusahaan manufaktur yang terdaftar di BEI tahun 2013-2018.

3. Nilai koefisien ukuran KAP adalah 10,179. Hal ini menunjukkan bahwa setiap perusahaan yang menggunakan KAP the big fouryang diukur dengan dummy akan mengalamiaudit report lag lebih lama 10,179 hari di bandingkan dengan KAP non the big four. Hal ini menunjukkan bahwa Ukuran KAP memiliki pengaruh positif terhadapaudit report lag perusahaan manufaktur yang terdaftar di BEI tahun 2013-2018.

4. Nilai koefisien solvabilitas adalah 0,281 artinya setiap solvabilitas meningkat sebesar 1 satuan yang diukur dengan DAR akan meningkatkan audit report lag sebesar 0,281 hari. Hal ini menunjukkan bahwa solvabilitas memiliki pengaruh positif terhadap audit report lag perusahaan manufaktur yang terdaftar di BEI tahun 2013-2018. 
5. Nilai koefisien umur perusahaan adalah-0,327artinya setiap umur perusahaan bertambah 1 tahun akan menurunkan audit report lag sebesar 0,327 hari. Hal ini menunjukkan bahwa umur perusahaan memiliki pengaruh negatif terhadap audit report lagperusahaan manufaktur yang terdaftar di BEI tahun 2013-2018.

\section{Uji Koefisian Determinasi}

Berdasarkan hasil pengelohan data yang telah dilakukan, hasil koefisen determinasi akan disajikan pada tabel di bawah ini:

Tabel 3 Hasil Koefisien Determinasi

\begin{tabular}{|c|c|c|c|c|c|}
\hline \multicolumn{6}{|c|}{ Model Summary ${ }^{b}$} \\
\hline Model & $\mathrm{R}$ & R Square & $\begin{array}{c}\text { Adjusted R } \\
\text { Square }\end{array}$ & $\begin{array}{l}\text { Std. Error of the } \\
\text { Estimate }\end{array}$ & Durbin-Watson \\
\hline 1 & $.304^{a}$ & .092 & .068 & 18.09633 & 1.998 \\
\hline
\end{tabular}

Sumber : Data sekunder diolah, 2020

Berdasarkan tabel 3 diatas diperoleh nilai $\mathrm{R}$ Square sebesar 0,092 $(9,2 \%)$ ini berartivariabel bebas yaitu pergantian auditor, ukuran KAP, solvabilitas dan umur perusahaan secara bersama-sama mempengaruhi variabel dependen yaitu audit report lag sebesar 0,092 (9,2\%). Sedangkan $90,8, \%$ ditentukan oleh variabel lain yang tidak dibahas dalam penelitian ini.

\section{Pengujian Hipotesis Secara Parsial (Uji t)}

Uji t digunakan untuk mengetahui pengaruh variabel independen terhadap variabel dependen secara parsial. Hasil pengujian dengan uji t adalah sebagai berikut:

Tabel 4 Hasil Uji Parsial (Uji Statistik t)

Sumber : Data sekunder diolah, 2020

\begin{tabular}{|c|c|c|c|c|c|c|}
\hline \multicolumn{7}{|c|}{ Coefficients $^{\mathrm{a}}$} \\
\hline \multirow{2}{*}{\multicolumn{2}{|c|}{ Model }} & \multicolumn{2}{|c|}{ Unstandardized Coefficients } & \multirow{2}{*}{$\begin{array}{l}\text { Standardized } \\
\text { Coefficients } \\
\text { Beta } \\
\end{array}$} & \multirow[b]{2}{*}{$\mathrm{t}$} & \multirow[b]{2}{*}{ Sig. } \\
\hline & & B & Std. Error & & & \\
\hline 1 & (Constant) & 62.483 & 6.384 & & 9.788 & .000 \\
\hline & Pergantian Auditor & -.063 & 2.916 & -.002 & -.022 & .983 \\
\hline & Ukuran KAP & 10.179 & 3.203 & .256 & 3.178 & .002 \\
\hline & Solvabilitas & .281 & .065 & .371 & 4.304 & .000 \\
\hline & Umur Perusahaan & -.327 & 227 & -.133 & -1.443 & .151 \\
\hline
\end{tabular}


Berdasarkan hasil uji statistik pada tabel diatas menunjukkan bahwa: Variabel pergantian auditor memiliki thitung sebesar $-0,022<$ dari $t_{\text {tabel }}$ yaitu 1,97580 dengan tingkat signifikansi sebesar 0,983>0,05 maka $\mathrm{H}_{1}$ ditolak, yang berarti bahwa pergantian auditor berpengaruh negatif dan tidak signifikan terhadap audit report lag.

Variabel ukuran KAP sebesar 3,178> dari tabel yaitu 1,97580, dengan tingkat signifikansi sebesar 0,002 $<0,05$ maka $\mathrm{H}_{2}$ ditolak, yang berarti bahwa ukuran KAP secara parsial berpengaruh positif dan signifikan terhadap audit report lag.

Variabel solvabilitas memiliki thitung sebesar 4,304 > dari tabel yaitu 1,97580 dengan tingkat signifikansi sebesar $0,000<0,05$ maka $\mathrm{H}_{3}$ diterima, yang berarti bahwa solvabilitas secara parsial berpengaruh positif dan signifikan terhadap audit report lag.

Variabel umur perusahaan memiliki thitung sebesar $-1,443<$ dari $t_{\text {tabel }}$ yaitu 1,97580 dengan tingkat signifikansi sebesar 0,151>0,05 maka $\mathrm{H}_{4}$ ditolak, yang berarti bahwa umur perusahaan secara parsial berpengaruh negatif dan tidak signifikan terhadap audit report lag.

\section{Pengujian Hipotesis Secara Simultan (Uji - F)}

Uji - F digunakan untuk menguji apakah variabel independen secara bersama-sama mempengaruhi variabel dependen. Berikut ini hasil pengujian hipotesis secara simultan adalah sebagai berikut :

\section{Tabel 5. Hasil Uji Simultan (Uji Statistik F)}

\begin{tabular}{|c|c|c|c|c|c|c|}
\hline & & & ANOVA $^{a}$ & & & \\
\hline & & $\begin{array}{l}\text { Sum of } \\
\text { Squares }\end{array}$ & Df & Mean Square & $\mathrm{F}$ & Sig. \\
\hline 1 & Regression & 9414.834 & 4 & 2353.709 & 7.217 & $.000^{\mathrm{b}}$ \\
\hline & Residual & 49245.525 & 151 & 326.129 & & \\
\hline & Total & 58660.359 & 155 & & & \\
\hline
\end{tabular}

a. Dependent Variable: Audit Report Lag

b. Predictors: (Constant), Umur Perusahaan, Pergantian Auditor, Ukuran KAP, Solvabilitas

Sumber : Data sekunder diolah, 2020

Berdasarkan tabel diatas menunjukkan bahwa nilai sig dari model penelitian ini adalah sebesar 0,000 dimana 0,000 < 0,05 dan $F_{\text {hitung }} 7,217>$ $F_{\text {tabel }}$ 2,43 artinya Pergantian Auditor, Ukuran KAP, Solvabilitas dan Umur Perusahaan berpengaruh positif dan signifikan secara simultan terhadap Audit Report Lag. 


\section{Pembahasan Hasil Penelitian}

a. Pengaruh Pergantian Auditor Terhadap Audit Report Lag

Berdasarkan hasil olah data statistik dapat dilihat nilai t hitung sebesar $\quad-0,022$ lebih kecil dari t tabel yaitu 1,97580 $(-0,022<1,97580)$ dengan tingkat signifikansi 0,983 lebih besar dari tingkat keyakinan 0,05 $(0,983>0,05)$. Hasil pengujian tesebut menyatakan bahwa pergantian auditor berpengaruh negatif dan tidak signifikan terhadap audit report lag, dengan demikian $\mathrm{H}_{1}$ ditolak.

Hal ini menunjukkan bahwa jika perusahaan melakukan pergantian auditor tidak mempunyai pengaruh yang signifikan terhadap audit report lag. Hal ini dikarenakan pergantian auditor dapat dilakukan jauh sebelum hubungan perusahaan dengan auditor lama berakhir. Sehingga auditor baru dapat mengatur waktu mereka untuk memahami lingkungan bisnis klien dan risiko audit klien dari awal sehingga tidak dapat mempengaruhi proses audit.

Hal ini sejalan dengan teori Arens, dkk (2011) yang mengungkapkan bahwa auditor yang baru melakukan perencanaan audit sebelum kontrak perusahaan dengan auditor lama berakhir, sedangkan pelaksanaan audit dan pelaporan dilaksanakan setelah kontrak perusahaan dengan auditor lama berakhir yaitu selama tiga sampai enam bulan, sehingga auditor tidak mengalami kesulitan.

Hasil penelitian ini sejalan dengan penelitian yang dilakukan oleh Apitaningrum (2017) yang menunjukkan bahwa pergantian auditor tidak mempengaruhi audit report lag secara signifikan. Karena pergantian auditor dalam suatu perusahaan dapat dilakukan jauh sebelum tanggal berakhirnya tahun buku, sehingga tidak akan mengganggu proses audit. Auditor dapat melakukan perencanaan awal dalam audit dengan baik dan dapat menjadwalkan pekerjaan mereka sehingga mereka dapat menyelesaikan audit dengan tepat waktu.

Hasil penelitian ini menolak penelitian Verawati \& widiakusuma(2016) bahwa perusahaan yang mengalami pergantian auditor membutuhkan waktu yang cukup lama dalam melaksanakan proses auditnya yaitu pergantian auditor berpengaruh positif terhadap audit report lag.

\section{b. Pengaruh Ukuran Kantor Akuntan Publik (KAP) Terhadap Audit Report Lag}

Berdasarkan hasil olah data statistik dapat dilihat nilai t hitung sebesar 3,178 lebih besar dari t tabel yaitu 1,97580 ( 3,178> 1,97580) dengan tingkat signifikansi 0,002 lebih kecil dari tingkat keyakinan 0,05 ( 
$0,002<0,05)$. Hal ini berarti bahwa Ukuran KAP berpengaruh positif dan signifikan terhadap Audit report lag .dengan demikian $\mathrm{H}_{2}$ ditolak.

Dari hasil ini menunjukkan bahwa jika perusahaan menggunakan KAP the big four maka audit report lagnya akan semakin lama. Hal ini disebabkan karena untuk menjaga reputasi yang bagus yang dimilikinya dan pandangan masyarakat banyak, membuat KAP the big four melakukan audit lebih hati-hati sehingga penyampaian laporan keuangan lebih lambat sedangkan KAP Non The Big Four memiliki kualitas yang sama. dengan $K A P$ The Big Four tetapi dalam penyampaian laporan keuangan lebihcepat dibandingkan KAP the big four. Hal ini dikarenakan KAP Non The Big Four juga memiliki auditor yang profesional dan bekerja secara efisien dan efektif.

Hal ini sejalan dengan pendapat Louis (2005) yang mengungkapkan bahwa KAP non the big four memiliki kemampuan yang sama dengan KAP the big four sehingga menghasilkan kualitas audit yang bagus.

Hasil penelitian ini mendukung hasil penelitian yang dilakukan oleh Widiastuti \& Kartika (2018) dan yang menyatakan bahwa ukuran KAP berpengaruh positif dan signifikan terhadap audit report lag , dan menolak hasil penelitian yang dilakukan oleh Maharani (2017) yang menyatakan bahwa ukuran KAP tidak berpengaruh terhadap audit report lag.

\section{c. Pengaruh Solvabilitas Terhadap Audit Report Lag}

Berdasarkan hasil olahan statistik dapat dilihat bahwa solvabilitas yang diukur dengan Debt to Asset Ratio menunjukkan nilai t hitung sebesar 4,304 lebih besar dari t tabel yaitu 1,97580 (4,304>1,97580) dengan tingkat signifikansi 0,000 lebih kecil dari tingkat keyakinan 0,05 $(0,000<0,05)$. Hal ini berarti solvabilitas berpengaruh positif dan signifikan terhadap audit report lag dan semakin tinggi nilai solvabilitas maka semakin panjang audit report lag perusahaan. Dengan demikian H3 diterima.

Tingginya rasio solvabilitas mencerminkan tingginya resiko keuangan perusahaan. Kesulitan keuangan merupakan berita buruk yang akan mempengaruhi kondisi perusahaan di mata masyarakat ataupun para calon investor. Pihak manajemen cenderung menunda penyampaian laporan keuangan perusahaan yang berisi berita buruk dan akan membuat auditor perlu meningkatkan kehati-hatian dan kecermatan yang dalam pengauditan, sehinggamenyebabkan proses audit yang relatif lebih 
panjang. Semakin tinggi nilai solvabilitas perusahaan, maka semakin panjang atau lama audit report lag.

Hal ini sejalan dengan teori Carslaw dan Kaplan (1991) mengungkapkan bahwa proporsi relatif dari hutang terhadap total aset mengindikasikan kondisi keuangan dari perusahaan. Proporsi kondisi keuangan dari perusahaan diindikasikan dari hutang terhadap total asset. Proporsi tingkat hutang yang tinggi terhadap total asset akan mempengaruhi kelangsungan hidup perusahaan sehingga memerlukan kecermatan dalam pengauditan.

Kasmir (2010), rasio solvabilitas merupakan rasio yang digunakan untuk mengukur sejauh mana aktiva suatu perusahaan yang dibiayai dengan utang perusahaan. Penggunaan hutang yang terlalu tinggi akan berdampak pada masa depan perusahaan sehingga membuat perusahaan akan lama melaporkan keuangan. Hal ini berarti tingginya jumlah hutang yang dimiliki perusahaan akan menyebabkan proses audit yang relatif lebih panjang. Proporsi hutang terhadap total aktiva yang tinggi membuat auditor perlu meningkatkan kehati-hatian dan kecermatan dalam pengauditan karena terkait dengan masalah kelangsungan perusahaan.

Hasil penelitian ini mendukung penelitian yang dilakukan Hasan \& Carvalho (2018) dan Maharani (2017) yang menyatakan bahwa solvabilitas berpengaruh positif dan signifikan terhadap audit report lag dan menolak hasil penelitian yang dilakukan oleh Harjanto (2017) yang menyatakan bahwa solvabilitas tidak mempunyai pengaruh yang signifikan terhadap audit report lag.

\section{d. Pengaruh Umur Perusahaan Terhadap Audit Report Lag}

Berdasarkan hasil olahan statistik pada tabel, pada umur perusahaan diperoleh koefisien regresi sebesar dapat dilihat bahwa umur perusahaan menunjukkan nilai t hitung sebesar -1,443 lebih kecil dari $\mathrm{t}$ tabel yaitu $1,97580 \quad(-1,443<1,97580)$ dengan tingkat signifikansi 0,151 lebih besar dari tingkat keyakinan $0,05(0,151>0,05)$. Hal ini berarti umur perusahaan berpengaruh negatif dan tidak signifikan terhadap audit report lag. Dengan demikian $\mathrm{H}_{4}$ ditolak.

Perusahaan yang sudah lama terdaftar di Bursa Efek Indonesia tidak mempengaruhi cepat atau lamanya waktu penyelesaian laporan audit. Karena, ketepatan waktu penyampaian laporan keuangan menjadi hal yang sangat diperhatikan oleh perusahaan baru maupun perusahaan yang lama. Perusahaan yang sudah lama terdaftar di BEI maupun perusahaan yang baru terdaftar BEI, apabila memiliki sistem manajemen 
yang baik, serta staf akuntan yang kompeten yang mampu menyajikan laporan keuangan dengan baik dan rasa tanggung jawab perusahaan dalam menyampaikan informasi mengenai kondisi keuangan perusahaan kepada pihak-pihak yang berkepentingan secara tepat waktu, maka hal tersebut akan sangat membantu auditor dalam pelaksanaan auditnya, sehingga auditor tidak membutuhkan waktu yang lama dalam proses auditnya. Dengan demikian, umur perusahaan tidak berpengaruh terhadap lamanya pelaporan keuangan secara tepat waktu.

Hal ini sejalan dengan penelitian Charviena \& Tjhoa(2016), perusahaan yang baru maupun perusahaan yang sudah lama terdaftar di BEI akan berusaha untuk segera menyelesaikan proses audit karena mereka diawasi secara ketat oleh para investor, pemerinta, dan lembaga lainnya.

Hal ini tidak sejalan penelitianSaemargani (2015) mengatakan bahwa umur perusahaan mempunyai pengaruh terhadap audit report lag. Semakin lama umur perusahaan, investor akan menilai bahwa perusahaan tersebut akan semakin efisien sehingga informasi yang relevan dapat disajikan tepat waktu adanya.

Hasil penelitian ini mendukung penelitian Widiastutu \& Kartika (2018) penelitian yang dilakukan Widiastutu \& Kartika (2018) yang menyatakan bahwa umur perusahaan tidak mempunyai pengaruh yang signifikan terhadap audit report lag .

Dengan demikian, Semakin lama perusahaan beroperasi dan terdaftar di Bursa Efek Indonesia atau semakin tua umur perusahaan tidak menjamin bahwa perusahaan tersebut akan tepat waktu dalam penyajian laporan keuangannya.

\section{KESIMPULAN DAN SARAN}

\section{Kesimpulan}

1. Pergantian auditor secara parsial berpengaruh negatif dan tidak signifikan terhadap audit report lag pada perusahaan manufaktur yang terdaftar di Bursa Efek Indonesia. Hal ini berarti perusahaan yang melakukan pergantian auditor tidak mempengaruhi audit report lag.

2. Ukuran Kantor Akuntan Publik (KAP) secara parsial berpengaruh positif dan signifikan terhadap audit report lag pada perusahaan manufaktur yang terdaftar di Bursa Efek Indonesia. Hal ini menunjukkan KAP yang berafiliasi dengan KAP the big four 
mengalami audit report lag yang lebih lama dibandingkan dengan KAP yang berafiliasi dengan KAP non the big four.

3. Solvabilitas secara parsial berpengaruh positif dan signifikan terhadap audit report lag pada perusahaan manufaktur sektor industri dasar dan kimia yang terdaftar di Bursa Efek Indonesia. Hal ini menunjukkan semakin tinggi solvabilitas, maka audit report lag semakin lama.

4. Umur perusahaan secara parsial berpengaruh negatif dan tidak signifikan terhadap audit report lag pada perusahaan manufaktur yang terdaftar di Bursa Efek Indonesia. Hal ini berarti perusahaan yang memiliki umur yang muda ataupun tua atau yang sudah lama terdaftar maupun baru tedaftar di BEI tidak mempengaruhi audit report lag.

\section{Saran}

Adapun saran-saran yang dapat penulis berikan sehubungan dengan keterbatasan yang terdapat dalam penelitian ini bahwa penelitian ini hanya menggunakan beberapa variabel sehingga kemungkinan variabel lain masih ada yang dapat mempengaruhi audit report lag, karena kecilnya hasil adjust $\mathrm{R}$ square sebesar 9,2\%. Peneliti selanjutnya juga dapat melakukan penelitian pada perusahaan yang berbeda atau selain perusahaan manufaktur yang terdaftar di BEI.

\section{DAFTAR PUSTAKA}

Andika, Windu. 2015. Pengaruh Profitabilitas, Solvabilitas, Likuiditas,Ukuran Perusahaan, Opini Audit Terhadap Audit Report Lag. Skripsi. Yogyakarta: Universitas Sanata Dharma.

Apitaningrum, Aprilia. 2017. Pengaruh pergantian auditor, opini audit, ukuran perusahaan, dan laba rugi terhadap audit report lag. Jurnal: SurakartaUniversitas Muhammadiyah.

Arfan Ikhsan, Dkk, 2013. Teori Akuntansi. Bandung : Cita Pustaka Media Bursa Efek Indonesia. Http//www.idx.co.id.

Carslaw, C.A.P.N. dan S.E. Kaplan. 1991 "An Examination of Audit Delay : Further Evidence from New Zealand", Accounting and Business Research 22 (85).

Chasanah, Irfa Ummul. 2017. Pengaruh Ukuran Perusahaan, Profitabilitas, Solvabilitas, Jenis Industri, Dan Afiliasi Kap Terhadap Audit Report Lag Pada Perusahaan Lq-45 Periode 2012-2015. Skripsi. Yogyakarta: Universitas Yogyakarta

Dewangga, Arga. 2015. Faktor-Faktor Yang Berpengaruh Terhadap Audit RepotLag. Skripsi. Semarang: Universitas Diponegoro. 
Donal E Kieso, dkk. 2007.Accounting Principles-Pengantar Akuntansi. Jakarta: Salemba Empat.

Fadoli, Imam. 2014. Pengaruh Faktor Internal dan Eksternal Terhadap Audit Report Lag (Studi Empiris pada Perusahaan Manufaktur dan Perbankan yang Terdaftar di BEI tahun 2008-2013). Jurnal Bisnis Akuntansi : Badan Penerbit Univeritas Diponegoro,4 (2), pp: 35-67.

Ghozali, Imam. 2018. Aplikasi Analisis Multivariate Dengan Program IMB SPSS 25.Universitas Diponegoro, Semarang.

Harjanto, Karina. 2017. Pengaruh Ukuran Perusahaan, Profitabilitas, Solvabilitas, dan Ukuran Kantor Akuntan Publik terhadap Audit Report Lag.Ultima Accounting Vol. 9 No. 2 Desember 2017.

Ikatan Akuntansi Indonesia (IAI). 2018. Standar Akuntansi Keuangan. Jakarta: Salemba Empat.

Iskandar, Meylisa Januar. 2010.Faktor-Faktor yang Mempengaruhi Audit Report Lag Pada Perusahaan yangTerdaftar di Bursa Efek Indonesia.Jurnal bisnis dan akuntansi Vol. 12, No. Desember 2010, Hlm. 175 - 186.

Ilhami, Maulana Fiqi. 2015. Audit Report Lag, (Penyakit) Tahunan Perusahaan

https://www.kompasiana.com/maulanafiqi/557007cc307a61a346bbf12 5/audit-report-lag-penyakit-tahunan-perusahaan.

Kartika, Andi. 2011. Faktor-Faktor Yang Mempengaruhi Audit Report LagPada Perusahaan Manufaktur Yang Terdaftar di BEI .Jurnal Dinamika Keuangan dan Perbankan Vol. ISSN: 1979-4878.

Kasmir. 2010. Pengantar Manajemen Keuangan . Jakarta:Kencana.

Kalinggajaya, Delia Alvorina. 2018. Pengaruh Profitabilitas, Solvabilitas, Ukuran KAP, Opini Audit dan Ukuran Perusahaan Terhadap Audit Report Lag Pada Perusahaan Manufaktur. Skripsi.Yogyakarta: Universitas Islam Indonesia.

Lianto, Novice \& Budi Hartono Kusuma. 2010. Faktor-Faktor Yang Berpengaruh Terhadap Audit Report Lag. JURNAL BISNIS DAN AKUNTANSI Vol. 12, No. 2, Agustus 2010, Hlm. 98 - 107

Maharani, Terry. 2017. Pengaruh Ukuran Perusahaan, Profitabilitas, Solvabilitas dan Ukuran KAP terhadap Audit Report Lag Pada Perusahaan Yang Terdaftar di BEI. Skripsi. Bandar Lampung: Universitas Lampung.

Mulyadi. 2002. Auditing. Buku I EdisiKeenam. Jakarta: SalembaEmpat.

Otoritas Jasa Keuangan. Http// www. Ojk. Go. Id

Pramaharja, Brian. 2015. Faktor- Faktor Yang Berpengaruh Terhadap AuditReport Lag Pada Perusahaan Manufaktur. Skripsi. Semarang: Universitas Diponegoro. 
Peraturan Otoritas Jasa Keuangan (OJK) Nomor 29/POJK.04/2016.

Putri,Kiki Ayu. 2018. Pengaruh Ukuran Perusahaan, Umur Perusahaan, Dan Profitabilitas Terhadap Audit Report Lag (Studi Empiris Di Perusahaan Pertambangan Yang Terdaftar Di Bei Tahun 2013-2015). Skripsi. Makassar: Universitas Hasanuddin.

Saemargani, Fitria Ingga. 2015. PengaruhUkuran Perusahaan, Umurperusahaan , UkuranKapdanOpini Auditor TerhadapAudit Report Lag( Studikasuspadaperusahaan LQ45 yang Terdaftar di BEI tahun 2011-2013). Jurnal Nominal Vol. 4 No.2. Yogyakarta: UniversitasNegeri Yogyakarta.

Suginam. 2016. Faktor-Faktor Yang Mempengaruhi Audit Report Lag Pada Perusahaan Sektor Perdagangan Jasa Dan Investasi Yang Terdaftar Di Bursa Efek Indonesia.Majalah Ilmiah Informasi dan Teknologi Ilmiah, Volume : XI, Nomor : 1, September 2016 ISSN: 2339-210X

Sugiyono. 2017. MetodePenelitian Pendekatan Kuantitatif, Kualitatif, Kombinasi, dan $R \& D$. Bandung: Alfabeta.

Syamsul Bahri, Khojanah Hasan \& Bernardete De Carvalho. 2018. Pengaruh Ukuran Perusahaan, Umur Perusahaan, Profitabilitas, Solvabilitas Dan Ukuran Kantor Akuntan Publik Terhadap Audit Report Lag. Conference on Innovation and Application of Science and Technology (CIASTECH 2018) Universitas Widyagama Malang, 12 September 2018 ISSN Cetak : 2622-1276 ISSN Online : 2622-1284.

Tambunan, Pinta Uli. 2014. PengaruhOpini Audit, Pergantian Auditor danUkuran Kantor AkuntanPublik (KAP) TerhadapAudit Report LagPada Perusahaan Manufaktur Yang Terdaftar Di Bursa Efek Indonesia. Jurnal. Padang: Universitas Negeri Padang.

Widiastuti, Ika Destriana Dan Andi Kartika. 2018. Ukuran Perusahaan, Profitabilitas, Umur Perusahaan, Solvabilitas Dan Ukuran Kap Terhadap Audit Report Lag. Jurnal Dinamika Akuntansi, Keuangan dan Perbankan, , Vol. 7, No. 1, Hal: 20 - 34 Mei 2018 ISSN: 26564955 .

Verawati, Ni Made Adhika dan Made Gede Wirakusuma. 2016. Pengaruh Pergantian Auditor, Reputasi Kap, Opini Audit dan Komite Audit pada Audit Repot Lag. E-Jurnal Akuntansi Universitas Udayana Vol.17.2. November (2016): 1083-1111 ISSN: 2302-8556 